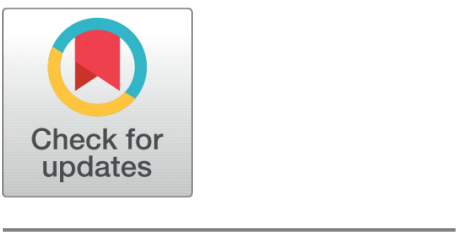

OPEN ACCESS

Received: 16.11.2020

Accepted: 22.12 .2020

Published: 04.01.2021

Citation: Jayashree Lakshmi P, Vanmathi Selvi K (2020) Genetic analysis of low-density polyethylene degrading bacteria from plastic dump sites. Indian Journal of Science and Technology 13(48): 4732-4738. https://doi.org/ 10.17485/IJST/v13i48.2066

* Corresponding author.

jayashreeimb@gmail.com

Funding: None

Competing Interests: None

Copyright: (c) 2020 Jayashree Lakshmi \& Vanmathi Selvi. This is an open access article distributed under the terms of the Creative Commons Attribution License, which permits unrestricted use, distribution, and reproduction in any medium, provided the original author and source are credited.

Published By Indian Society for Education and Environment (iSee)

ISSN

Print: 0974-6846

Electronic: 0974-5645

\section{Genetic analysis of low-density polyethylene degrading bacteria from plastic dump sites}

\author{
P Jayashree Lakshmi ${ }^{1}{ }^{*}, \mathrm{~K}_{\text {Vanmathi Selvi }}{ }^{\mathbf{1}}$ \\ 1 Department of Microbiology, Sri Akilandeswari Women's College, Vandavasi, T.V.Malai, \\ Tamil Nadu, India
}

\section{Abstract}

Objective: The principle goal of this examination is to screen bacteria having the ability to debase Low density polyethylene. Bacteria were disengaged from different plastic dump locales. Methods: The secludes acquired were screened for their capacity to use polyethylene as sole carbon source in the mineral salt medium (MSM). Among the isolated strains, Pseudomonas putida and Pseudomonas fluorescens could able to utilize Low Density Polyethylene (LDPE) as carbon source. Further to the preliminary screening, gene specific primers for alkane monooxygenase was synthesized and gradient PCR was performed to determine the presence of alkane monooxygenase gene in the bacterial isolates. Results: Among the four bacteria selected, three bacteria such as Pseudomonas putida and Pseudomonas fluorescens could able to express ALKB gene. Hence, those two bacteria may produce the key enzyme alkane monoxygenase, which is a crucial enzyme for the biotransformation of many xenobiotic compounds including LDPE. Conclusion: From this investigation it is inferred that organisms local to soil can possibly degradeplastic with proper method of time.

Keywords: Low density polyethylene; Biodegradation; Bacteria; alkane monoxygenase; invitro Biodegradation assay

\section{Introduction}

Plastics are engineered polymers comprising little natural monomer units joined into a long chain by covalent bonds shaped during a polymerization response. The term 'plastic' is gotten from the Greek word 'plastikos', which signifies 'to form ${ }^{(1)}$. Natural and inorganic crude materials, for example, carbon, silicon, hydrogen, nitrogen, oxygen and chloride are utilized for the production of plastics. Plastics are light weighted, sturdy, erosion safe, solid and cheap.

The fundamental kinds of plastic in like manner use are polyethene or polyethylene (PE), polystyrene (PS), polyvinyl chloride (PVC), polypropylene or polypropene (PP), polyethylene terephthalate (PET) and polyurethane (PUR). Polythene finds a wide scope of utilizations in people day by day use on account of its simple preparing ${ }^{(2,3)}$. Numerous creatures bite the dust of waste plastics either by being trapped in the waste plastic snares or by gulping the waste plastic garbage. A portion of the plastic items cause 
human medical conditions since they imitate human hormone. Consuming plastics as a rule produce some toxic gases like furans and dioxins which are perilous ozone depleting substances and assume a significant function in ozone layer exhaustion. ${ }^{(4,5)}$

Cremation, reusing and land filling are a portion of the customary techniques for taking care of plastic squanders. Be that as it may, these techniques are exorbitant and regularly make new ecological troubles. When contrasted with different strategies, biodegradation is contamination agreeable. ${ }^{(6)}$ Natural debasement is the wonder of organic change of natural mixes by living creatures especially microbes. Organic material can be corrupted vigorously with oxygen, or anaerobically, without oxygen. ${ }^{(7)}$

Presence of alkB gene in the selected strains were determined to rule out its efficacy to be explored as potential microbe to be employed for biodegradation of LDPE. Pseudomonas putida, Pseudomonas fluorescens, Bacillus subtilis \& Streptococcus mutans were selected strains. In that Psuedomonas spp. showed the presence of alkB gene.

\section{Materials and Methods}

\section{Plastic samples}

Polyethylene bags(40 microns) were collected from local market. Low Density Polyethylene powder( $<400$ micron) was purchased from Vijaya scientific company, Chennai, Tamil Nadu, India.

\section{Soil Sample collection}

Soil samples are gathered from four distinctive plastic unloading destinations in Chennai (Pallikaranai, Perungudi, Medavakkam and Sirucheri). They were gathered at a profundity of 3 to $5 \mathrm{~cm}$, in a sterile polythene pack. They were firmly stuffed and deliberately moved to the lab for the examination and put away at $4{ }^{\circ} \mathrm{C}$ aseptically.

\section{Physico-chemical analysis of soil}

Various parameters like $\mathrm{pH}$, Temperature, Moisture content, Alkalinity and Organic matter were tested to study the soil morphology.

\section{Isolation of Bacteria}

$1 \mathrm{~g}$ of soil was suspended independently in $9 \mathrm{ml}$ sterile saline and serially diluted. $10^{-5}$ and $10^{-6}$ dilutions were plated on supplement agar and hatched at $37^{\circ} \mathrm{C}$ for $24-48$ hours to isolate diverse bacterial strains. The colonies with various settlement morphology were chosen and sub refined in the particular media for additional utilization.

\section{Screening of Polyethylene degrading organisms}

The isolated organisms were screened for its ability to degrade polyethylene using mineral salt medium. Low density polyethylene powder was added to mineral salt medium at a final concentration of $0.1 \%(\mathrm{w} / \mathrm{v})$ respectively. The medium was continuously shaken at $120 \mathrm{rpm}$ in shaker for 1 hour, and then sterilized. ${ }^{(8)}$ The medium was poured in a sterile petriplate and allowed to solidify, wells were cut and $20 \mu \mathrm{l}$ culture of isolated organisms was added to the well. The plates were then incubated at room temperature for 2-4 weeks and observed for growth around the wells.

\section{Identification of Polyethylene degrading organisms}

From the isolated bacteria, totally four bacterial organisms were screened based on their ability to utilize polyethylene as sole carbon source. Bacteria were identified on the basis of microscopic examination and biochemical analysis according to Bergey's manual of Determinative Bacteriology. ${ }^{(8)}$

\section{Invitro Biodegradation assay}

Polyethylene (LDPH) films were cut in to pieces $(3 \times 3 \mathrm{~cm})$, disinfected with Tween 20 , distilled water and $70 \%$ ethanol for $30 \mathrm{~min}$, air dried for $15 \mathrm{~min}$ in laminar air flow chamber. Polyethylene films were weighed (Initial weight). $1 \mathrm{ml}$ of culture was inoculated in $250 \mathrm{ml}$ Erlenmeyer flask containing $100 \mathrm{ml}$ of MSM broth (autoclaved) and polyethylene films. ${ }^{(9)}$ As for control, uninoculated MSM broth supplemented with LDPE films were maintained under similar conditions. The flasks are placed in a rotary shaker. Different flasks will be kept in a shaker for a month at $37^{\circ} \mathrm{C}$.

\section{Determination of Dry weight of Residual Polyethylene}

To measure the accurate weight of residual polyethylene, microbial biofilms were washed off from the polyethylene surface with $2 \%$ (v/v) Sodium Dodecyl Sulfate (SDS) overnight, followed by rinsing with distilled water. This is air dried and weighed (Final weight).

$$
\text { Percentage }(\%) \text { degradation }=\text { Initial weight }- \text { Final weight } / \text { Initial weight } \times 100
$$

\section{Isolation of Chromosomal DNA}

The bacterial culture was grown at $37^{\circ} \mathrm{C}$ for 24 hours in $\mathrm{LB}$ broth and $10 \mathrm{ml}$ of culture was taken and centrifuged at $5000 \mathrm{rpm}$ for 10 minutes. $1 \mathrm{~mL}$ extraction buffer was added. $1 \mathrm{ml}$ of lysozyme solution was added to the above suspension and incubated at $37^{\circ} \mathrm{C}$ for 30 minutes with intermittent stirring. After the incubation, the lysis was completed by adding $2 \mathrm{~mL}$ of $25 \%$ SDS 
solution. The preparation was heated for 10 minutes at $60^{\circ} \mathrm{C}$ in a water bath and finally cooled down to room temperature. $5 \mathrm{M}$ perchloride was sufficiently added to the lysed preparation to the final concentration of $1 \mathrm{M}$. Equal volume of chloroform: isoamyl alcohol was added to the lysed preparation suspended in $1 \mathrm{M}$ perchloride and shaken slowly (30-60 oscillations/min) in a highly stoppered flask for 30 minutes at room temperature. The resulting emulsion was separated by centrifuging for 5 $\mathrm{min}$ at $10000 \mathrm{rpm}$ at room temperature. After centrifugation, the top clear aqueous phase was carefully pipetted out from the coagulated protein emulsion, at the inner phase. The aqueous phase containing the nucleic acid was placed in the beaker. The nucleic acid solution was gently stirred with a sterilized glass rod and 2 volumes of $95 \%$ ethanol was added slowly down the side of the beaker. So that the ethanol was layered over the viscous aqueous phase. The stirring was continued up to the preparation to mix throughout the phase and spool all of the gelatinous thread like DNA rich precipitate on the glass rod. The excess fluid was drained off from the spooled crude DNA by pressing the rod against the wall of the beaker until no further fluid can be squeezed from the spooled preparation if the squeezing was not done sufficiently, the alcohol adhering the crude DNA will make it difficult to dissolve the DNA.

The crude DNA was dissolved in $9 \mathrm{ml}$ of diluted saline citrate. To the even suspension, $1 \mathrm{~mL}$ of $3 \mathrm{M}$ acetate and $1 \mathrm{M}$ EDTA were added and transferred the preparation to $100 \mathrm{ml}$ beaker containing $5.4 \mathrm{ml}$ of isopropanol. For the storage of DNA, the crude DNA was dissolved in $9 \mathrm{ml}$ of saline citrate and stored at $2^{\circ} \mathrm{c}$ with few drops of chloroform. The isolated DNA was further analyzed by Nanovue- spectrophotometry for purity and gel electrophoresis for integrity.

PCR

Gene expression study to determine alkB gene was carried out. $38 \mu \mathrm{l}$ of sterile triple distilled water was added to a sterile microfuge tube. Then $5 \mu \mathrm{l}$ of 10X Taq polymerase assay buffer with $\mathrm{MgCl} 2$ were added. $3 \mu \mathrm{l}$ of $2.5 \mathrm{~mm} \mathrm{dNTP}$ mixed solution and $1 \mu \mathrm{l}$ of control template DNA was added. Followed by that, $1 \mu \mathrm{l}$ of each of forward and reverse primers were added. The reaction mixture was layered with $50 \mu \mathrm{l}$ of mineral oil to avoid evaporation. The amplification was carried out using the following reaction conditions.

1. Initial denaturation at $94^{\circ} \mathrm{C}$ for $1 \mathrm{~min}$

2. Denaturation at $94^{\circ} \mathrm{C}$ for 30 seconds

3. Annealing at $48^{\circ} \mathrm{C}$ for 30 seconds

4. Extension at $72^{\circ} \mathrm{C}$ for 1 minute

5. Final extension at $72^{\circ} \mathrm{C}$ for 2 minutes

\section{Results and Discussion}

Soil samples were collected from four different plastic dump sites in Chennai to isolate polyethylene (LDPH) degrading bacteria from soil. Totally 20 isolates were obtained from soil sample collected from four different sites in Chennai. First sample was from Pallikaranai dump site. Second sample was obtained from Perungudi dump site. Third one was obtained from Medavakkam dump site. The last sample was collected from Sirucheri waste disposal site.

Totally 20 isolates were obtained from soil sample collected from four different sites in Chennai (Figure 1 ). At that point, these isolates are utilized to consider debasement of Low-thickness polyethylene. Various physiochemical parameters were tested i.e. $\mathrm{pH}(6-9)$, temperature $\left(25-37^{\circ} \mathrm{C}\right)$, moisture content (11- $\left.49 \%\right)$, total alkalinity $(30-60 \mathrm{mg} / \mathrm{l})$ and organic matter $(0.1$ 2.3\%). (Table 1 )

Soil samples were serially diluted from $10^{-1}$ to $10^{-10}$. Then $10^{-5}$ and $10^{-6}$ dilutions from each sample was plated in nutrient agar medium for isolation of bacteria. After incubation, various colonies were formed. From bacterial mixed culture, colonies were sub cultured and streaked on nutrient agar medium to isolate bacterial strains.

All the isolates do not have the ability to utilize plastic as sole carbon source. Therefore, they were screened to check their ability to utilize polyethylene (LDPH) as their sole carbon source. The isolated cultures were added to the wells cut on mineral salt medium (MSM) agar and the plates were then incubated at $30-37^{\circ} \mathrm{c}$ for $2-4$ weeks. The isolates which showed growth on MSM agar plates were able to utilize polythene (LDPH) as the sole carbon source.

Nissida suggested that clear zone technique is a convenient method for the investigation of plastic degrading bacteria. Bacteria secrete the extracellular enzymes which degrade the polymeric substances into water-soluble materials, resulting into the formation of a clear zone around the microbial culture, indicating utilization of polyethylene powder as the sole carbon source. ${ }^{(9-11)}$

Absolutely four organisms were screened dependent on their capacity to use polyethylene as their sole carbon source. Among the 4 bacterial strains obtained, 2 from Perungudi, 1 from Pallikaranai and other 1 from Medavakkam. None of the isolate utilized polyethylene from Sirucheri dump site. 


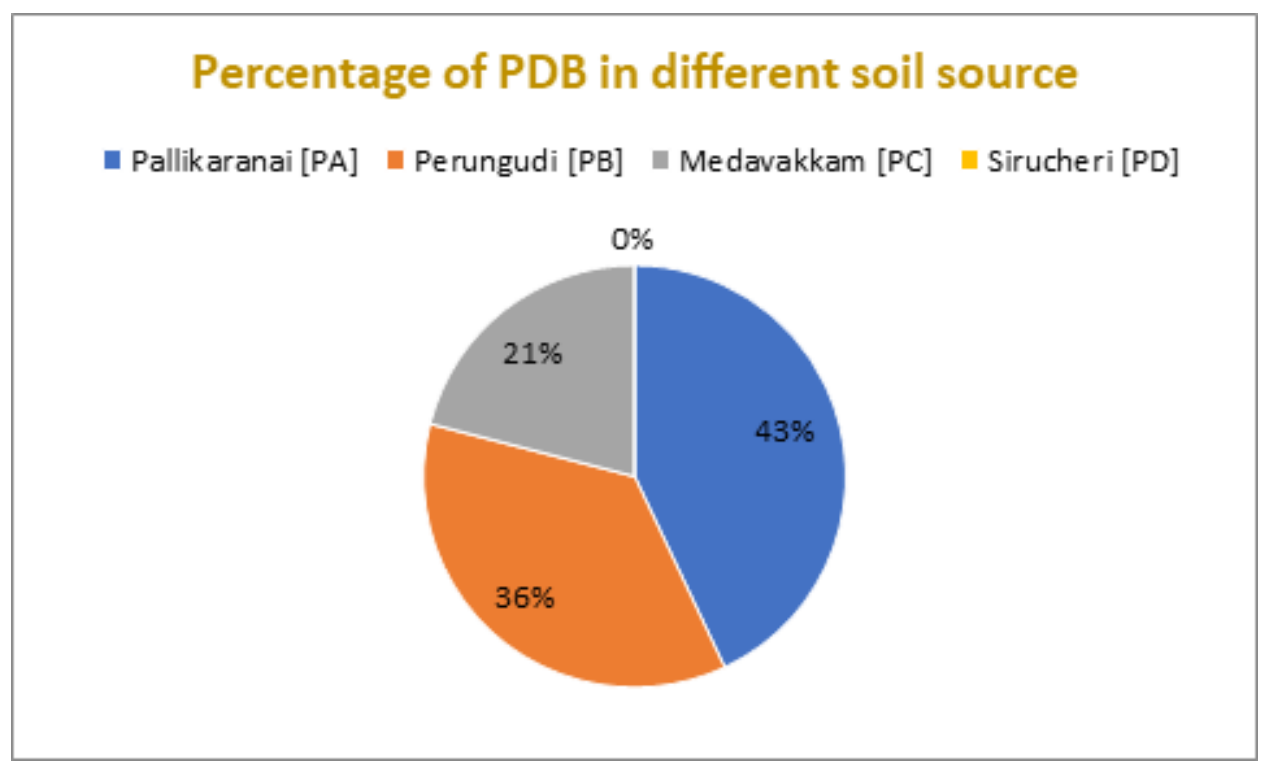

Fig 1. Soil source and No. of polyethylene degrading bacterial [PDB] isolates obtained

Table 1. Physico chemical parameters of soil sample

\begin{tabular}{llllll}
\hline Soil sample & $\mathrm{p}^{\mathrm{H}}$ & Temperature $\left({ }^{\circ} \mathrm{C}\right)$ & Total alkalinity $(\mathrm{mg} / \mathrm{l})$ & Organic matter $(\%)$ & Moisture content $(\%)$ \\
\hline PA & 6.4 & 27.9 & 50 & 0.82 & 11.85 \\
PB & 7.5 & 27.6 & 40 & 1.56 & 11.26 \\
PC & 6.9 & 28.5 & 60 & 0.52 & 10.38 \\
PD & 8.2 & 35.2 & 30 & 0.92 & 13.50 \\
\hline
\end{tabular}

Absolutely four organisms were screened dependent on their capacity to use polyethylene as their sole carbon source. The screened Bacterial isolates were identified according to Bergy's manual of Determinative Bacteriology by performing gram staining technique, motility test and biochemical tests (Table 2 ).

Table 2. Biochemical characteristics of Bacterial isolates

\begin{tabular}{|c|c|c|c|c|c|c|}
\hline S.No & Tests & $\begin{array}{l}\text { Bacillus subtilis } \\
\text { (PAB1) }\end{array}$ & $\begin{array}{l}\text { Pseudomonas fluo- } \\
\text { rescens }(\mathrm{PBB} 1)\end{array}$ & $\begin{array}{l}\text { Pseudomonas Putida } \\
\text { (PBB3) }\end{array}$ & $\begin{array}{l}\text { Streptococcus } \\
\text { (PCB2) }\end{array}$ & mutans \\
\hline 1 & Gram staining & (+) ve rods & $(-)$ ve rods & $(-)$ verods & (+) vecocci & \\
\hline 2 & Motility & Motile & Motile & Non- motile & Non- motile & \\
\hline 3 & Catalase & + & + & - & - & \\
\hline 4 & Oxidase & Variable & + & - & - & \\
\hline 5 & Indole & - & - & + & + & \\
\hline 6 & Methyl Red & - & - & + & + & \\
\hline 7 & Voges Proskauer & + & - & - & - & \\
\hline 8 & Citrate & + & + & + & - & \\
\hline 9 & Urease & - & - & + & - & \\
\hline 10 & Nitrate Reduction & + & + & - & - & \\
\hline 11 & Glucose Utilization & + & + & + & + & \\
\hline 13 & Gelatin hydrolysis & + & + & - & - & \\
\hline 14 & Spore staining & Spore forming & Non-sporing & Non-sporing & Non-sporing & \\
\hline
\end{tabular}

Results of degradation of polyethylene by isolates were calculated and mentioned in Table 3 and the percentage differences were graphically represented in Figure 2 . 
Table 3. Results of degradation of polyethylene by isolates

\begin{tabular}{lllll}
\hline S.No & Bacterial isolate & Initial weight $(\mathrm{mg})$ & Final weight $(\mathrm{mg})$ & Weight loss $(\%)$ \\
\hline 1 & PAB1 & 40 & 27 & 32 \\
2 & PBB1 & 40 & 25 & 37 \\
3 & PBB3 & 40 & 24 & 40 \\
4 & PCB2 & 40 & 33 & 17 \\
\hline
\end{tabular}

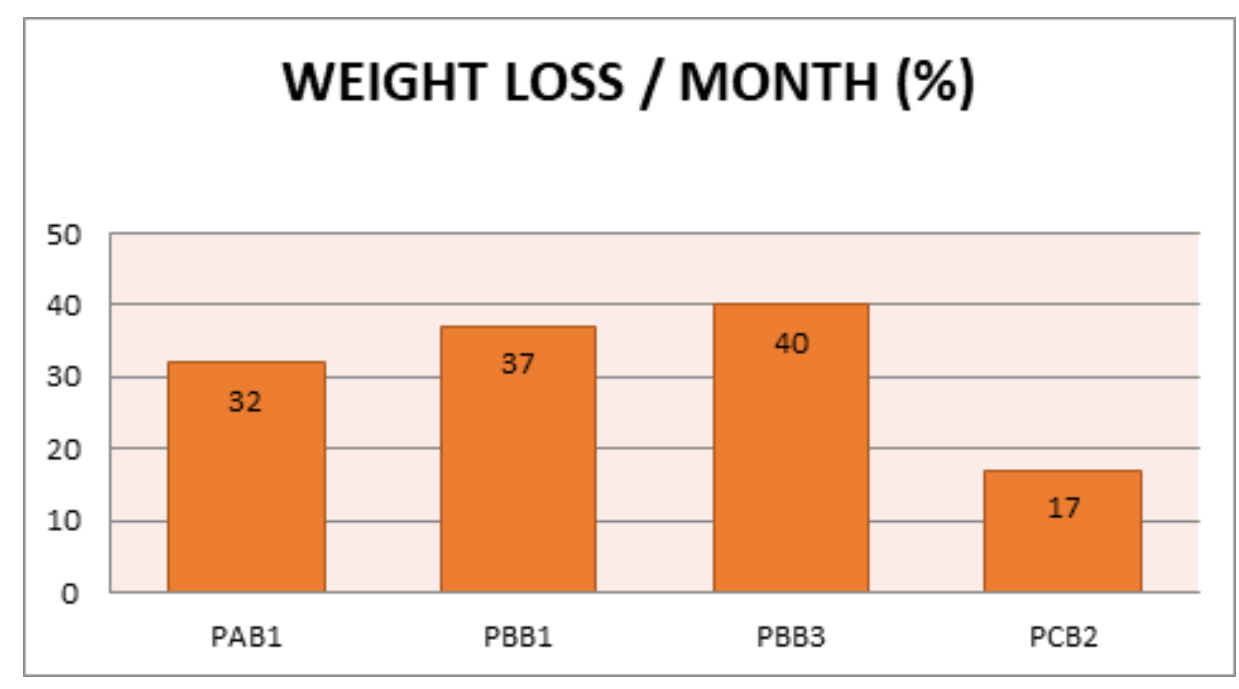

Fig 2. Weight loss difference in percentage

High degradation was determined by weight loss of LDPE. Hence, PBB1 and PBB3 shows strong degradation. Therefore, Bacterial isolates like Pseudomonas fluorescens and Pseudomonas putida were taken for molecular study [PCR].

PCR amplification

ALKB gene specific primer synthesized by Biosource Ltd, Bangalore was used to determine the alkane monooxygenase gene and the genomic DNA from the selected isolates were used as a template and amplified by PCR and result is depicted in Figure 3. The product size of the alkB gene is $330 \mathrm{bp}$ and which was determined triplicates by gel electrophoresis.

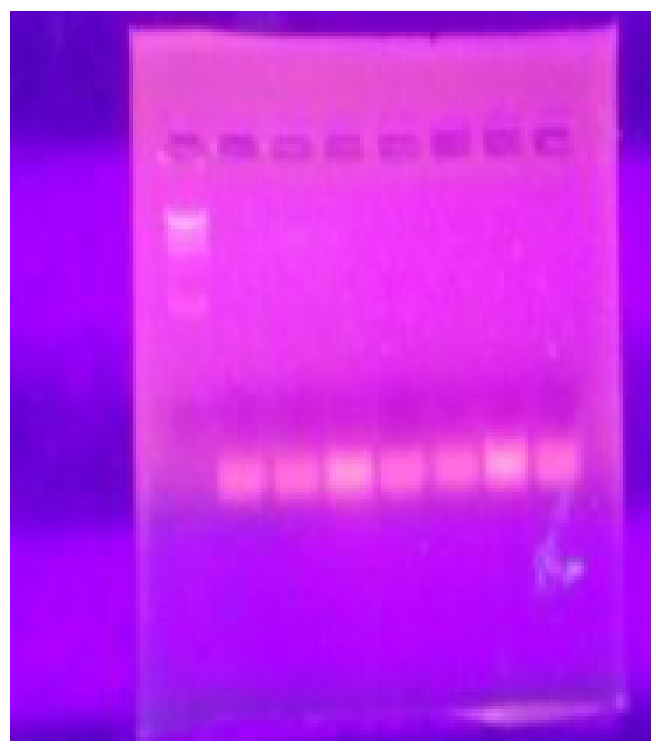

Fig 3. PCR Amplified product of ALKB gene 
Lane 1 - 500bp ladder

Lane 2, 3 and 4 - Genomic DNA of Pseudomonas putida,

Lane 5, 6 and 7 -Pseudomonas fluorescens,

Heiss-Blanquet $\mathrm{S}$ et al. ${ }^{(12)}$ implemented the PCR technique for the determination of total DNA of the soil sample at Bavaria, Germany. They acquired 58 PCR products whose bands seemed at $550 \pm 50 \mathrm{bp}$. The hybridization of the PCR products produced 42 alkB clones attached with the alkB complementary probe. Examination of the alkB homology by means of the cDNA library cloning exposed that the genetic consistency between the $42 \mathrm{alkB}$ clones was in the range of 57 90\%. On the other hand, the PCR for the total DNA of the agricultural soil samples were identified 21 alkB genes among which the 2 alkB genes displayed genetic change less than $1 \%$ and the 19 alkB genes showed the genetic homogeny in the variance of $50 \sim 90 \%$.

Saadoun I et al. ${ }^{(13)}$ determined the amount of the gene in the soil testers to measure the ecological significance of the bacteria for the biodegradation of alkanes of short-chain size by means of the alkB. They observed that the alkB be influenced by the environmental and ecological conditions and that the amount of the alkB was higher in the soil polluted with hydrocarbons. Very nearly all the genes identified as alkB existed in P. aeruginosa, P. putida and P. mendocina. Saadoun et al. identified microbes from an oil polluted soil and investigated their growth using diesel oil as a sole carbon source. They determined the presence of the alkB through the PCR analyses.

Two groups of the bands appeared at 316 334 bp and 460 550 bp, correspondingly, on the agarose gel, and the alkB genes showed bands between 320 and $550 \mathrm{bp}$. Smits et al. ${ }^{(14)}$ observed that a single alkB precise primer cannot notice all the alkane degrading microbes due to the microbial species-specificity in the discovery of alkane degraders through the PCR method. The alkB was found to be completely different dependent on the microbes due to the great dissimilarity in the alkB sequence. ${ }^{(15)}$

\section{Conclusion}

Bacteria for LDPE biodegradation was isolated from a plastic dump wastes soil sample and were identified depending on their ability to utilize LDPE as carbon source. They were identified asb Bacillus subtilis, Pseudomonas fluorescens, Pseudomonas putida \& Streptococcus mutans through phenotypic methods. Among the isolates, Pseudomonas putida (PBB3) showed high rate of LDPE degradation (40\%). The isolated strains mineralized LDPE whose initialweight was in the range of $40 \mathrm{mg}$ with considerable action at $37^{\circ} \mathrm{Cunder}$ the organized circumstances. Though, the biodegradation action reduced with upsurge in the weight of LDPE. Presence of alkB gene in the selected strains were determined to rule out its efficacy to be explored as potential microbe to be employed for biodegradation of LDPE.

\section{Acknowledgment}

We are thankful to our Principal, Head of the department \& other faculties in our department for their support to carry out our research work.

\section{Funding}

No funding sources

\section{Conflict of interest}

None declared

\section{Ethical approval}

The study was approved by the Institutional Ethics Committee by Akilandes and its ID number : 241/2019

\section{References}

1) Rani A, Singh P. Screening of Polyethylene Degrading Fungi from Polyethylene Dump Site. Int J Chemtech Res. 2017;10(3):699-704.

2) Begum A, Varalakshmi M, Umamagheswari B. Biodegradation of Polythene Bag using Bacteria Isolated from Soil. Int J Curr Microbiol App Sci. 2015;4(11):674-680.

3) Arutchelvi J, Sudhakar A, Arkatkar M, Doble. Sumit Bhaduril and Parasu Veera Uppara. Biodegradation of Polyethylene and Polypropylene. Indian J Biotechnol. 2008;7(1):9-22.

4) Deepika S, Madhuri J, R. Biodegradation of low-density polyethylene by bacteria from garbage soil. J Exp Biole Agri 2015, Sci;3(1):12-20.

5) Divyalakshmi S, Subhashini A. Screening and Isolation of Polyethylene Degrading Bacteria from Various Soil Environments. J Env Sci, Toxicol \& Food technol. 2016;10(12):1-7. 
6) Agrawal P, Singh RK. Breaking down of polyethylene by Pseudomonas species. Int J Sci, Eng Res. 2016;7(3):342-348.

7) Holt JG, Krieg NR, Sneath PHA, Staley JT, Williams ST, Hensyl WR. Bergy's Manual of Determinative Microbiology. 9th ed. and others, editor. 1994.

8) Kamble A, Shubhamsingh T, Tejashree S. Isolation of Plastic Degrading Micro-organisms from Soil Samples Collected at Various Locations in Mumbai. India Int Res J Environment Sci. 2015;4(3):77-85.

9) Kannahi M, Sudha P. Screening of polythene and plastic degrading microbes from Muthupet mangrove soil. J Chem Pharm Res. 2013;5(8):122-127.

10) Fathima N, Siluvaikirubagari K, Aneeshia C. Polyethylene degradation by microbes isolated from municipal solid waste. Int J Adv Sci Res Management. 2018;3(11):21-27.

11) Kathiresan K. Polythene and Plastics-degrading microbes from the mangrove soil. Rev Biol Trop. 2003;51(3):629-634.

12) Heiss-Blanquet S, Benoit Y, Marechaux C, Monot $F$. Assessing the role of alkane hydroxylase genotypes in environmental samples by competitive PCR. Journal of Applied Microbiology. 2005;99(6):1392-1403. Available from: https://dx.doi.org/10.1111/j.1365-2672.2005.02715.x.

13) Saadoun I, Alawawdeh M, Jaradat Z, Ababneh Q. Growth of Streptomyces spp. from hydrocarbon-polluted soil on diesel and their analysis for the presence of alkane hydroxylase gene (alkB) by PCR. World Journal of Microbiology and Biotechnology. 2008;24(10):2191-2198. Available from: https://dx.doi.org/10.1007/s11274-008-9729-z.

14) Smits THM, Rothlisberger M, Witholt B, van Beilen JB. Molecular screening for alkane hydroxylase genes in Gram-negative and Gram-positive strains. Environmental Microbiology. 1999;1(4):307-317. Available from: https://dx.doi.org/10.1046/j.1462-2920.1999.00037.x.

15) Kohno T, Sugimoto Y, Sei K, Mori K. Design of PCR primers and gene probes for general detection of Alkane-Degrading bacteria. Microbes and Environments. 2002;17(3):114-121. Available from: https://dx.doi.org/10.1264/jsme2.17.114. 